\title{
David Bowie and Transmedia Stardom
}

Addressing the interart, intertextual, and intermedial dimensions of David Bowie's sonic and visual legacy, this book considers more than five decades of a career invested with a star's luminosity that shines well beyond the remit of pop music.

The book approaches the idea of the star David Bowie as a medium in transit, undergoing constant movement and change. Within the context of celebrity studies, the concept of stardom provides an appropriate frame for an examination of Bowie's transmedial activity, especially given his ongoing iconic signification within the celestial realm. While Bowie has traversed many mediums, he has also been described as a medium, which is consistent with the way he has described himself. With contributions from a wide range of disciplinary areas and countries, each chapter brings a fresh perspective on the concept of stardom and the conceptual significance of the terms 'mediation' and 'navigation' as they relate to Bowie and his career.

Containing a multitude of different approaches to the stardom and mediation of David Bowie, this book will be of interest to those studying celebrity, audio and visual legacy, and the relationships between different forms of media.

The chapters in this book were originally published as a special issue of Celebrity Studies.

Ana Cristina Mendes is an Assistant Professor of English Studies in the School of Arts and Humanities at the University of Lisbon, Portugal. Her areas of specialization are cultural and postcolonial studies, with an emphasis on the representations and reception of alterity in the global cultural marketplace. She serves on the board of the Association of Cultural Studies.

Lisa Perrott is a Senior Lecturer of Media Studies at the University of Waikato, Hamilton, New Zealand. Her research specialties include cultural studies, animation, and transmedia, with an emphasis on the relations between audiovisual media, popular music, and the avant-garde. Lisa is a Co-editor of the Bloomsbury book series New Approaches to Sound, Music and Media. 



\section{David Bowie and Transmedia Stardom}

Edited by

Ana Cristina Mendes and Lisa Perrott

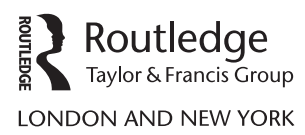


First published 2020

by Routledge

2 Park Square, Milton Park, Abingdon, Oxon, OX14 4RN

and by Routledge

52 Vanderbilt Avenue, New York, NY 10017

Routledge is an imprint of the Taylor \& Francis Group, an informa business

(C) 2020 Taylor \& Francis

All rights reserved. No part of this book may be reprinted or reproduced or utilised in any form or by any electronic, mechanical, or other means, now known or hereafter invented, including photocopying and recording, or in any information storage or retrieval system, without permission in writing from the publishers.

Trademark notice: Product or corporate names may be trademarks or registered trademarks, and are used only for identification and explanation without intent to infringe.

British Library Cataloguing in Publication Data

A catalogue record for this book is available from the British Library

ISBN13: 978-0-367-35675-0

Typeset in Myriad Pro

by codeMantra

\section{Publisher's Note}

The publisher accepts responsibility for any inconsistencies that may have arisen during the conversion of this book from journal articles to book chapters, namely the inclusion of journal terminology.

\section{Disclaimer}

Every effort has been made to contact copyright holders for their permission to reprint material in this book. The publishers would be grateful to hear from any copyright holder who is not here acknowledged and will undertake to rectify any errors or omissions in future editions of this book. 


\section{Contents}

Citation Information vi vil

Notes on Contributors viii

Introduction: Navigating with the Blackstar: the mediality of David Bowie

Ana Cristina Mendes and Lisa Perrott

1 Constellating stardom, Berlin-style: Bowie, Christiane F, Hedi Slimane

Susan Ingram

2 Football, fashion and unpopular culture: David Bowie's influence on

Liverpool Football Club casuals 1976-79

Mairi MacKenzie

3 Celebrity conferences as confessional spaces: the aca-fan memory traces of David Bowie's stardom

Toija Cinque

4 Is Bowie our Kierkegaard?: A theory of Agency in Fandom

Amedeo D'Adamo

5 'Oh man, I need TV when I got T. Rex': Bowie and Bolan's otherworldly carnivalesque intermediality

Alison Blair

6 Telling lies: the interviews of David Bowie

Elizabeth McCarthy

7 Transition transmission: media, seriality and the Bowie-Newton matrix Dene October

8 Time is out of joint: the transmedial hauntology of David Bowie Lisa Perrott

9 'Look up here, I'm in heaven': how visual and performance artist David Jones called attention to his physical death

Gareth Schott

Index 


\section{Citation Information}

The chapters in this book were originally published in Celebrity Studies, volume 10, issue 1 (March 2019). When citing this material, please use the original page numbering for each article, as follows:

\section{Introduction}

Introduction: Navigating with the Blackstar: the mediality of David Bowie Ana Cristina Mendes and Lisa Perrott

Celebrity Studies, volume 10, issue 1 (March 2019) pp. 4-13

\section{Chapter 1}

Constellating stardom, Berlin-style: Bowie, Christiane F, Hedi Slimane

Susan Ingram

Celebrity Studies, volume 10, issue 1 (March 2019) pp. 14-24

\section{Chapter 2}

Football, fashion and unpopular culture: David Bowie's influence on Liverpool Football Club casuals 1976-79

Mairi MacKenzie

Celebrity Studies, volume 10, issue 1 (March 2019) pp. 25-43

\section{Chapter 3}

Celebrity conferences as confessional spaces: the aca-fan memory traces of David Bowie's stardom

Toija Cinque

Celebrity Studies, volume 10, issue 1 (March 2019) pp. 44-59

\section{Chapter 4}

Is Bowie our Kierkegaard?: A theory of Agency in Fandom

Amedeo D'Adamo

Celebrity Studies, volume 10, issue 1 (March 2019) pp. 60-74

\section{Chapter 5}

'Oh man, I need TV when I got T. Rex': Bowie and Bolan's otherworldly carnivalesque intermediality

Alison Blair

Celebrity Studies, volume 10, issue 1 (March 2019) pp. 75-88 


\section{Chapter 6}

Telling lies: the interviews of David Bowie

Elizabeth McCarthy

Celebrity Studies, volume 10, issue 1 (March 2019) pp. 89-103

\section{Chapter 7}

Transition transmission: media, seriality and the Bowie-Newton matrix

Dene October

Celebrity Studies, volume 10, issue 1 (March 2019) pp. 104-118

\section{Chapter 8}

Time is out of joint: the transmedial hauntology of David Bowie

Lisa Perrott

Celebrity Studies, volume 10, issue 1 (March 2019) pp. 119-139

\section{Chapter 9}

'Look up here, I'm in heaven': how visual and performance artist David Jones called attention to his physical death

Gareth Schott

Celebrity Studies, volume 10, issue 1 (March 2019) pp. 140-152

For any permission-related enquiries please visit:

http://www.tandfonline.com/page/help/permissions 


\section{Notes on Contributors}

Alison Blair is a PhD Candidate at the University of Otago, Dunedin, New Zealand. Her research interests include popular music studies, media studies, and the 1970s popular culture. Her academic interest in rock music is informed by a lifelong interest in music history, and a background in both music journalism and music retail.

Toija Cinque is a Senior Lecturer in Communication at Deakin University, Australia. Her main research interest lies in exploring the intersections between stardom and celebrity, digital ethnography, audience, and reception studies, with other studies in social and screen media and communications.

Amedeo D'Adamo is the founding Dean and then President of the Los Angeles Film School, USA, and is an Adjunct Professor in Directing at the Università Cattolica del Sacro Cuore, Italy. His theoretical work concerns the ways nationalism, racism, and forms of idealism are encoded in culture. As a filmmaker, his features have been to festivals such as Rome, Miami, Austin, Torino, and others.

Susan Ingram is an Associate Professor in the Department of Humanities at York University, Toronto, Canada, where she coordinates the Graduate Diploma for Comparative Literature and is affiliated with the Canadian Centre for German and European Studies and the Research Group on Language and Culture Contact. Her research interests revolve around the institutions of European cultural modernity and their legacies.

Mairi MacKenzie is a fashion historian and curator based in Glasgow, UK. She is a Research Fellow in Fashion and Textiles at Glasgow School of Art, UK, and a Visiting Lecturer at Glasgow University, UK. Her current research is concerned with the relationship between popular music and fashion, social histories of perfume, and the history of dressing up and going out in Glasgow.

Elizabeth McCarthy is a Lecturer in English, Media, and Cultural Studies at the Institute of Art, Design + Technology, Ireland. Her research and teaching interests include genre studies, American noir fiction, youth culture and rebellion in the 1950s and 1960s, literature and the visual arts/media, and sexuality and criminality in the Long Eighteenth Century. She is the co-founder of the online academic journal The Irish Journal of Gothic and Horror Studies.

Ana Cristina Mendes is an Assistant Professor of English Studies in the School of Arts and Humanities at the University of Lisbon, Portugal. Her areas of specialization are cultural and postcolonial studies, with an emphasis on the representations and reception of alterity in the global cultural marketplace. She serves on the board of the Association of Cultural Studies. 
Dene October is a Research-Oriented Senior Lecturer at the University of the Arts London, UK, where he teaches various theory options in fan, design, and media cultures, including David Bowie Studies. Among other works, he has contributed chapters to several collections on David Bowie.

Lisa Perrott is a Senior Lecturer of Media Studies at the University of Waikato, Hamilton, New Zealand. Her research specialties include cultural studies, animation, and transmedia, with an emphasis on the relations between audiovisual media, popular music, and the avant-garde.

Gareth Schott is an Associate Professor in Screen and Media Studies at the School of Arts at the University of Waikato, Hamilton, New Zealand. His current research interests are focused on media representation of death and dying in the modern era. 
